\title{
Ecological-and-economical aspects of assessment of management of the city-forming organizations in the construction industry
}

\author{
Kymbat Kunanbayeva ${ }^{1, *}$, Alexander Gorovoy ${ }^{2}$ and Andrey Butyrin ${ }^{3}$ \\ ${ }^{1}$ Financial University under the Government of the Russian Federation, Leningradsky, 49, \\ Moscow, 125993, Russia \\ ${ }^{2}$ Saint Petersburg National Research University of Information Technologies, Mechanics \\ and Optics, ITMO University, 49 Kronverksky pr., St. Petersburg, 197101, Russia \\ ${ }^{3}$ Moscow State University of Civil Engineering, Yaroslavskoe shosse, 26, Moscow, \\ 129337, Russia
}

\begin{abstract}
The matters of the mechanism of management of development of the city-forming organizations of the construction industry, forms of interference of development of the city-forming organizations and monoprofile municipal unit are defined in the article. The main methodical approaches to the assessment of effectiveness of realization of the mechanism of management of development of the city-forming organizations of construction industry are proved. Assessment of effectiveness of realization of the mechanism of management of development of the city-forming organizations to the sphere of production of construction materials are considered according to the ecological-andeconomic aspects of sustainable development, including economic efficiency, social efficiency, environmental efficiency.
\end{abstract}

\section{Introduction}

The processes happening in the country, the changed conditions of activity of the industrial enterprises have demanded reorientation of the principles of activity of the industrial enterprises in management of their development.

The present stage of development causes the need of formation of new approach of management of development by the enterprises which will answer global external and internal challenges. The special place of new approaches of management of development by the industrial enterprises in formation belongs to the city-forming organizations which are the basis of functioning of mono-profile municipal units, performing important functions of life support of the mono-town. Management of the city-forming organizations is aimed at providing competitiveness in the market and also promotes improvement of economic and social situation in the mono-town.

Nowadays 319 mono-towns, which conditions of development is defined by financial and economic activity of the city-forming organizations, function in the territory of the Russian

\footnotetext{
*Corresponding author: Kunanbaeva_kymbat@mail.ru
} 
Federation. According to the Resolution of the Government of the Russian Federation of July 29, 2014 No. 709 one of the criteria of reference of the mono-town to the first category are the data on the development of the city-forming organization (the termination of activity or initiation of the procedure of insolvency), market condition or development of the construction industry. At the present stage of the development one third of mono-towns belongs to the first category of mono-towns, where there is a real threat of destruction of business and deterioration in economic-and-social situation of the city [1].

According to the structurization of the city-forming organizations among the branches of the national economy the most part belongs to ferrous metallurgy, the wood-working industry, construction industry, etc.

Construction industry as one of the key industries of the national economy is the main allied industry in other branches where the city-forming organizations are concentrated. So, closely depend on dynamics of development of the construction industry branch of ferrous metallurgy, nonferrous metallurgy, sawing production and woodworking industry, etc. The construction industry as the large supplier of products and services of key branches of the industry is the driver of economic development. Thus, stimulation of the branch development, particularly the city-forming organizations, focused on the production of construction materials, contributes to the development of allied industries.

Management of development of the city-forming organizations of the construction industry, considering the existence of city-forming functions, assumes the managerial influence directed to high-quality transformation of the city-forming organization as the social-and-economic system in the short-term and long- term on the basis of increase in its competitiveness, and effective interaction with mono-profile municipal unit, the making favorable impact on region economic-and-social situation in general.

Considering, close dependence of economic-and-social situation of the mono-town on the effectiveness functioning on its territories of the city-forming organization, the research of the matters connected with management of development of the economic entities which are mainly defining state of the economy of municipal units in the territory of which they function is very relevant [2-4].

\section{State of the Art}

Management of the development of the city-forming organization of the construction industry which is the social-and-economic system the development of the integrated approach demanding development of the mechanism of management of development where key aspect is development of methodical approaches of assessment of this mechanism necessary. It is expedient to carry out the assessment of the mechanism of management of development of the city-forming organizations of construction industry from a position of ecological-and-economic aspects of sustainable development.

Nowadays the term "mechanism", borrowed from the technical science is widely used in the economic sciences, and it is defined as the way of the organization of social production with its methods and forms, legal-and-economic incentives, i.e. conscious application of relations of production in economic practice $[5,6]$.

As for the city-forming organization, the mechanism of management of development has no unambiguous definition. In the general view, the mechanism of management is defined as a component of the control system, which provides impact on external and internal factors on which condition the efficiency of activity of an subject of management depends. The mechanism of management of development of the city-forming organization represents set of the economic structures, institutes, forms and methods of managing providing steady functioning as separately taken subject of managing, and municipal economy in general. The main objective of the specified mechanism consists in ensuring coherence of interests of 
owners of business, management and labour collective of the city-forming organization with the concept of development of mono-profile municipal unit when accounting opinion of surrounding community. At the same, time also the feedback allowing reaching stability of economic-and-social situation of municipal economy in general, having to be created cause and effect.

The mechanism of management of development of the city-forming organization assumes implementation of some functions and interaction of the subjects of management of development (figure 1).

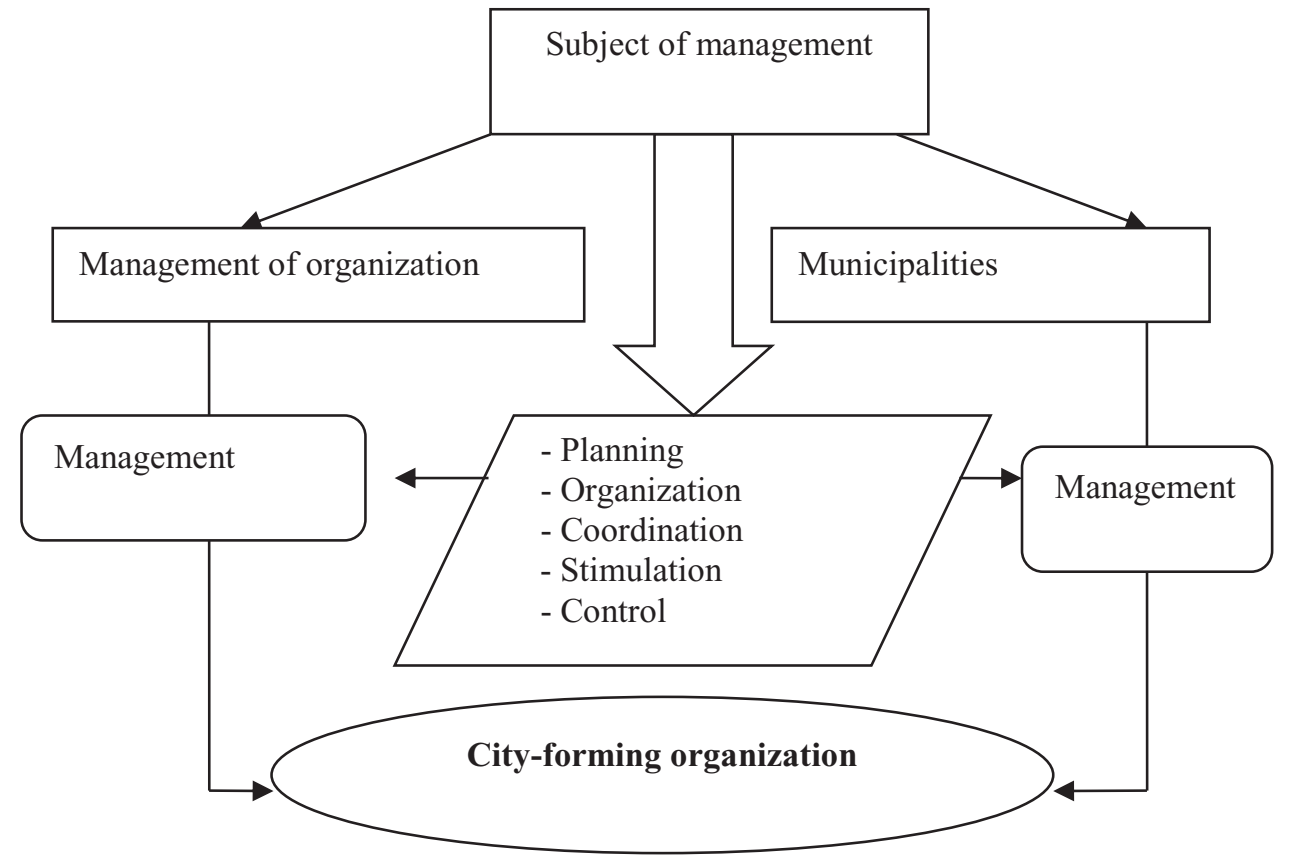

Fig. 1. Interaction of management subjects of development by the city-forming organization (it is made by the author).

\section{Results}

According to the author, the key moment of the realization of the mechanism of management of development of the city-forming organizations is the assessment of its efficiency, and formation of the suggestion for the improvement of management of their development. It is offered to consider the assessment of efficiency of realization of the mechanism within the ecological-and-economic aspects of sustainable development. The efficiency of the mechanism of management of development of the city-forming organizations has to be estimated in the following aspects: the economic efficiency reflecting effectiveness of activity of the city-forming organizations; considering city-forming function of the organization, from the point of view of social efficiency; ecological-and-economic efficiency.

At the heart of economic efficiency there is an analytical indicator reflecting assessment of the company taking into account all sources of her financing: debt obligations, preference shares, share of minority and common stocks.

Ultimate goal of management of development of the city-forming organizations of building industry is increase in cost of the organization, which allows to resolve issues of economic, social, innovative, ecological development and promotes increase in safety of 
work of personnel and protection the environment. Increase in cost of the organization will promote:

- the growth of the salary and other various social payments to workers;

- the growth of the volumes of investment;

- the increase in a possibility of updating of the fixed business assets and decrease in wear;

- the increase in free financial resources for reinvestment in innovative projects;

- the increase in payments at development of personnel and increase in their competences;

- the increase in an opportunity to take part in city projects (repair and improvement in the monotown, holding cultural, sporting, educational events, etc.).

The economic efficiency of realization of the mechanism of management of development of the city-forming organizations of building industry is set by means of the acceptable range of numerical values of cost of the organization. For this purpose it is possible to use the following range of acceptable values:

$$
E V_{o} \leq E V_{1}
$$

where, $E V_{o}$ - the cost of the city-forming organization in the basic year; $E V_{1}$ - cost of the city-forming organization in the current year.

One of the analytical indicators is EBITDA which shows the activity and profitability of the organization without depreciation charges. On the one hand, the use of EBITDA allows to analyse the profitability of the organization irrespective of its debt to creditors, the state and also from a depreciation charge method. But on the other hand, so far as concerns development of the city-forming organization, under development we have to a mean the ability of the improvement of its state in the long term, and payments of interest, taxes profit can significantly reduce, and the values for development of the city-forming organization can be exhausted.

As the assessment of economic efficiency it is offered to estimate the share of underexploitation of innovative capacity of the city-forming organization of building industry. So, one of the important criteria of the development of the city-forming organization not only building industry, but also all the branches of the national economy is the ability most effectively to realize objectives at the maximum use of the available resources: intellectual; material; financial; personnel; infrastructure; additional sources of increase in results of innovative activity.

Intensive development of the markets causes the city-forming organizations to increase competitiveness on the basis of release of hi-tech production, introduction of innovative administrative solutions. The ability of the city-forming organization to improvement and updating, characterizes her innovative potential. For calculation of the share of underexploitation of innovative capacity of the city-forming organization possibly calculation of coefficient which allows to define what part of income it is possible to develop due to release of hi-tech production (innovative):

$$
U_{E I C_{c f o}}=1-\frac{D_{i a}}{D_{c}}
$$

where, $U E I C_{s f o}$ - coefficient of underexploitation of innovative capacity of the city-forming organization; $D_{i a}$ - income from the innovative activity (release of hi-tech production); $D c$ - core income.

The range of acceptable values for the coefficient of underexploitation of innovative capacity of the city-forming organization is: 


$$
1 \leq U E I C \text { cfo } \geq 0
$$

At the most effective use of the available economic resources the innovative capacity of the city-forming organization will be equal to 0 .

Improvement of indicators of social-and-economic development of the mono-town and social development of the city-forming organization of the construction industry is the cornerstone of social efficiency.

Considering city-forming function of the organizations, undoubtedly, it is necessary to emphasize its social obligations. One of the criteria of development of the city-forming organization is effective distribution of net profit (effective structure of net profit). Maximizing costs of social needs on condition of the existence of free resources from profit is necessary for the establishment of "social justice" and the increase in the welfare of the population of the mono-town:

$$
C E \equiv C_{p}+C_{c u w}+C_{c i}+C_{i t}+C_{c m s}
$$

where, $\mathrm{C}_{\mathrm{e}}-$ social expenses of the city-forming organization (Labour costs, obligatory assignments on social needs do not enter); $C_{P}$ - costs of development of personnel (training, training); $C_{c u w}$ - costs of non-state pension provision of workers, social support of socially unprotected workers; $C_{C I}$ - costs of social infrastructure, namely construction of affordable housing for employees of the organization; $C_{i t}$ - costs of improvement and treatment of employees of the organization; $\mathrm{C}_{\mathrm{cms}}$ - costs of the organization to workers cultural and mass, sporting events, etc.

Improvement of indicators of ecological development and environment protection is the cornerstone of ecological-and--economic efficiency. Considering, that activity of most the city-forming organizations has raw focus, the efficiency of development of the organizations has criteria of ecological character, environment protection and reduction of harm against harmful emissions. Especially it should be noted that the important point decrease in volumes of harmful emissions on one resident is relevant for the city-forming organizations having the high level of emissions unhealthy the person and the city in general. Especially it is worth emphasizing mono-towns with the city-forming organizations of ferrous and nonferrous metallurgy, where harmful emissions cause serious oncological diseases. For some of such mono-towns it is possible to offer calculation of the sum of expenses for causing potential harm to health of the worker:

$$
C_{p h}=\left(P_{a} * C_{a m s}\right)-C_{i t}
$$

where, $C p h$ - the sum of expenses for causing potential harm to the health of employees of the city-forming organization; $P a$ - average number of the staff of the city-forming organization; $C_{a m s}$ - costs of additional medical care; $C_{i t}$ - costs of improvement and treatment of employees of the city-forming organization.

Depending on the field of activity of workers it is possible to vary the payment for the medical services (on categories of harm for the worker health, for example, the worker of main/auxiliary production, administration, etc.). The sum of expenses, spent for the improvement purposes is subtracted, the rest is the potential sum of the city-forming organization which it has to be able to pay to workers for rendering necessary medical services. 


\section{Conclusion}

Performance criterion of social efficiency characterizes the city-forming organization as socially responsible and also its activity is recognized to be effective as besides implementation of important economic-and-social obligations, the organization has funds for realization of social policy.

Performance criterion of economic efficiency characterizes the city-forming organization as the competitive effectively realizing activity in the conditions of global external and internal challenges.

Performance criterion of ecological-and-economic efficiency promotes the realization of environmental policy by the city-forming organization within the environment protection and increase safety conditions of work of workers.

Realization of the mechanism of management of development of the city-forming organizations it is designed to improve not only conditions of development of the cityforming organizations, but also ecological-social-and-economic position of mono-towns.

Thus, assessment of effectiveness of realization of the mechanism of management of the development of the city-forming organizations will promote developments of further managerial decisions, both for management of the organization, and for the municipal authorities and also will promote justification of ecological decisions on the implementation of projects of development of the city-forming organizations of building industry.

\section{References}

1. A.N. Ryakhovskaya, O.G. Kryukova, Housing-and -municipal services 8-9, 18-24 (2012)

2. A. Mottaeva, World of economy and law 11, 7-14 (2011)

3. I.V. Makiyeva, I.V. Krivogov, Bulletin of the Financial university 5, 5-14 (2011)

4. N.A. Kharitonova, Works of Free economic society 197, $214-222$ (2016)

5. L.I. Abalkin, Chosen works. On the way to reform. An economic mechanism of the developed socialist society. New type of economic thinking. Reorganization: ways and problems (Economy, Moscow, 2000)

6. URL: http://samlib.ru/o/onoprienko_w_i/vakaliklub.shtml (2012)

7. N.A. Kharitonova, E.N. Kharitonova, V.N. Pulyaeva, K.B. Kunanbayeva, Economy in the industry 4, 24-31

8. An. Mottaeva, V. Lukinov, A. Mottaeva, Economy and interpreneurship 8(49), 34-37 (2014)

9. I.A. Merkulina, Assessment of economic parameters of projects at implementation of capital investments in infrastructure facilities the energy industry, (Publishing and trade corporation "Dashkov and To", Moscow, 2018)

10. I.A. Markina, A.V. Sharkova, Journal of Applied Economic Sciences 9(4), 687-693 (2014)

11. Y.V. Morozyuk, A.V. Sharkova, I.A. Merkulina, O.N. Vasilyeva, Journal of Environmental Management and Tourism 8-3(19), 507-515 (2017)

12. A.V. Trachuk, Transition to sustainable development as an object of research, in the book: Management of sustainable development (Real economy, $\mathrm{SPb}, 2015$ )

13. A.V. Trachuk, N.V. Linder, Innovations 4(222), 53-65 (2017)

14. A.O. Afolabi, P.F. Tunji-Olayeni, R.A. Ojelabi, O.I. Omuh, IOP Conference Series: Earth and Environmental Science 146(1), 012013 (2018) 